\title{
THE SEPARATION AND THE CONCENTRATION OF MINERALS FROM THE ZEOLITIC VOLCANIC TUFFS. ANALYTICAL CONSIDERATIONS
}

\author{
DUMITRU BULGARIU ${ }^{1}$
}

\begin{abstract}
The separation and concetration of minerals from zeolitic volcanic tuffs represent one of the problems for which the literature not offer, to much practically solutions. The experimental strategy used by as, for the separation minerals from zeolitic volcanic tuffs to comprise the following methods: heavy liquids separation; magnetic separation and electrophoresis separation. For zeolites, silica polymorphs, feldspars and other minerals separated from zeolitic volcanic tuffs, the work eighth conditions and the proper experimental strategy efficiency has been estabilish. The purity for mineral fractions can be separated has been between $95.0-99.6 \%$.
\end{abstract}

Key words: volcanic tuffs, zeolites, separation methods

\section{INTRODUCTION}

The work methods for the study of the geochemistry of the zeolitic volcanic tuffs include, almost all the time, different procedures of mineral separation and concentration. Most of the existent studies recommend the following sequence of methods (lorga, 1981; Bedelean \& Stoici, 1984; McBride, 1986; Anastasiu, 1986; Bă rbat \& Marton, 1989; Lă că tușu, 2000):

$$
\begin{gathered}
\text { Grinding } \rightarrow \text { Granulometric sorting } \rightarrow \text { Separation with heavy liquids } \rightarrow \\
\text { Magnetic separation. }
\end{gathered}
$$

Only in few papers is presented the analytic details of the work methods, the applicability limits and the efficiency of the separation methods in case of the zeolitic volcanic tuffs. In this paper, besides the methodological problems, we will also to refer of several aspects concerning the applicability and efficiency of the separation methods of the minerals from the volcanic tuffs, the analytical relevance of the obtained results by different separation methods and we want to present a new experimental strategy for the separation of the minerals from the zeolitic volcanic tuffs.

Using our experimental strategy, mineral fractions with $95.00-99.60 \%$ purity degree have been separated from the volcanic tuff samples. The work samples is zeolitic minerals like: clinoptilolite, analcime, volcanic glass, silica polymorphs, feldspars, biotite, muscovite and turmaline. 


\section{WORK METHODS}

The experimental strategy used by as, for the separation and concentration of minerals from the zeolitic volcanic tuffs (figure 1) included the following work stages: (1)-the preparation of the zeolitic volcanic tuffs; (2)-the preparation of the work samples for separation; (3)-magnetic separation; (4)-separation with heavy liquids; (5)-analytical control of the separated mineral fractions; (6)-estimation of the efficiency of the separation methods and of the experimental strategy.

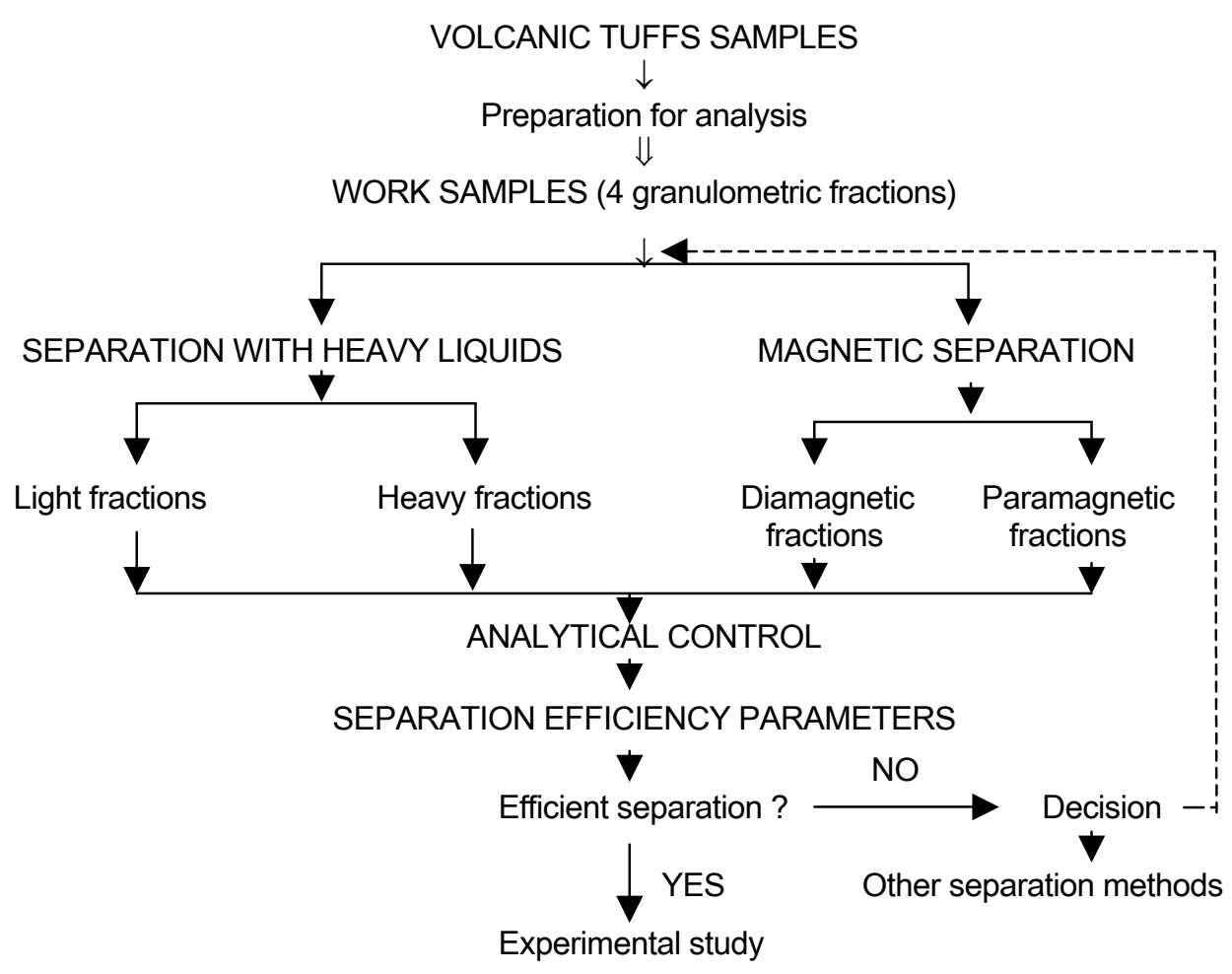

Fig. 1. The experimental strategy for the separation of the minerals from the zeolitic volcanic tuffs.

\section{Mineralogical material}

For this study we use a sample of riodacitic vitreocrystalloclastic volcanic tuff with medium granulation, zeolitized (clinoptilolite + analcime + mordenite) taken from Cluj Napoca area, "Iris" hill quarry (A.3-10 sample). The mineralogic composition of the A.3-10 volcanic tuff sample: volcanic glass: $62.70 \%$; silica polymorphous (quartz + cristobalite + amorphous silica): $2.15 \%$, total zeolites > $28.25 \%$ (clinoptilolite: $20.20 \%$; analcime: $6.25 \%$; mordenite: $1.80 \%$ ); total feldspars: $3.30 \%$ (plagioclases: $2.75 \%$ and orthoclases: $2.75 \%$ ), other minerals: $1.74 \%$ (calcite; montmorillonite: $0.48 \%$; biotite: $0.15 \%$; hornblende: $0.15 \%$; muscovite: $0.17 \%$; turmaline: $0.10 \%$; celadonite; apatite; zircon; limonite; goethite). For to establish the mineralogic composition were used ours original procedure (Bulgariu, 
1999, 2002) which includes X-ray diffraction determinations, IR spectroscopy and thermal analysis. Four granulometric fractions have been used: $\varnothing_{1}=0.160-0.100$ $\mathrm{mm} ; \varnothing_{2}=0.100-0.071 \mathrm{~mm} ; \varnothing_{3}=0.071-0.045 \mathrm{~mm}$ and $\varnothing_{4}>0.045 \mathrm{~mm}$, obtained through mechanical sieving of the ground lithologic material.

\section{Separation with heavy liquids}

The installation used by Bulgariu $(1999,2002)$ and Sabliovschi \& Bulgariu (2001) is different than those described in the literature (Tueva, 1954; lorga, 1981; Anastasiu, 1986). A cylindrical separation funnel has been used, with a capacity of $250 \mathrm{~cm}^{3}$, endowed with electrical heating mantle for to realized a precise control of temperature while the separation occur. For to increase the work speed, a vacuum filtration installation has been used, and the mineral fractions was collected in filterable crucibles (G.3 and G.4). The heavy liquid, used in thse experiments is bromoform. The bromoform specific gravity has been rigouros controlled by direct measurements (pycnometer method).

As a preliminary stage to separation, the chemical compatibility between bromoform and the minerals from the work sample has been tested. The experimental observations allowed the estimation of the relative aggressivity degree of the heavy liquids on the minerals from the work samples, the estimation of the optimum contact time and the mixture ratio between phases. In case of bromoform utilisation, for a single separation stage, has been use a quantity of 4-5 $\mathrm{g}$ of sample, a volume of $150 \mathrm{~cm}^{3}$ bromoform and the contact time between phases was of 20-45 minutes.

After an adequate washing with absolute ethilic alcohol, the mineral fractions separated with bromoform have been dried for 2 days using the silica gel desiccator and then in the drying stove (2 hours at a temperature of $50-60{ }^{\circ} \mathrm{C}$ ). After dried, the separated mineral fractions have been determinated by weighing.

\section{Magnetic separation}

An isodynamic magnetic separator of "Frantz L.1" type has been used. For the calibration of the magnetic separator we use an mixture of $\mathrm{Fe}\left(\mathrm{NH}_{4}\right)_{2}\left(\mathrm{SO}_{4}\right)_{2} \cdot 6 \mathrm{H}_{2} \mathrm{O}, \mathrm{NiSO}_{4} \cdot 6 \mathrm{H}_{2} \mathrm{O}$ and $\mathrm{CuSO}_{4} \cdot 5 \mathrm{H}_{2} \mathrm{O}$, with granulation of $0.100-$ $0.071 \mathrm{~mm}$. For to establish the optimum work conditions we have used ours original data, for a set of 4 standardes as well as data from the literature (McAndrew, 1957; Flinter, 1959; Febinskii et al. 1976; lorga, 1981; McBride 1986; Bulgariu, 2002). All the separations have been done with a constant longitudinal slope $\left(\varphi=15^{\circ}\right)$ and the determinations were not made for high power densities.

The work samples were passed 3-6 times through the magnetic separator, with a speed of 3,5-8 $\mathrm{g} / \mathrm{min}$, at the optimum pre-established working conditions (transversal slope and intensity of the supply power of the electromagnet). The separated mineral fractions were determined by weighing and then they were analytically controlled.

\section{Analytical control of the separated mineral fractions}

For to establish the efficiency of the separation methods, each separated mineral fraction has been thoroughly analytically controlled by: chemical analysis, X-ray diffraction, thermal analysis, infrared spectroscopy analysis, thermal analysis and microscopical studies on the binocular magnifier. 


\section{Estimation of separation efficiency}

The quantitative estimation of the separation outputs were realized on the basis of the following parameters (Liteanu et al., 1981; Jercan, 1983): recovery factor $(R)$, separation factor $(S)$ and enrichment coefficients $(\Delta)$. The values of these parameters was determined by using the experimental data for each separated mineral fraction and for several component minerals of the volcanic tuffs samples: zeolites (clinoptilolite and analcime), volcanic glass, silica, feldspars, muscovite, biotite etc. The variations of these analytical parameters have also been watched experimentally, considering the following factors: mineralogical composition and granulation of the volcanic tuff samples; chemical composition of the component minerals; the value of the transversal slope $(\Theta)$, the value of the electromagnet supply power (i) and the speed while passing through the separator, for the magnetic separations; the preliminary treatment of the work samples.

Table 1.

The experimental results obtained to fractionation of a volcanic tuff sample (A.3-10 sample, riodacitic tuff, vitreocrystalloclastic, zeolitized) by the magnetic method.

\begin{tabular}{|c|c|c|c|c|c|c|c|c|}
\hline \multirow[t]{2}{*}{ Separated minerals } & \multicolumn{4}{|c|}{ Paramagnetic fraction } & \multicolumn{4}{|c|}{ Diamagnetic fraction } \\
\hline & {$[\%]_{\mathrm{f}}$} & {$[\%]_{\mathrm{s}}$} & $\Delta, \%$ & $\delta, \%$ & {$[\%]_{\mathrm{f}}$} & {$[\%]_{\mathrm{s}}$} & $\Delta, \%$ & $\delta, \%$ \\
\hline Volcanic glass & 98.01 & 96.30 & 35.31 & 3.70 & 1.25 & - & - & - \\
\hline Muscovite & 0.26 & 98.00 & 0.09 & 2.00 & - & - & - & - \\
\hline Biotite & 0.23 & 98.45 & 0.08 & 1.15 & $\mathrm{u}$ & - & - & - \\
\hline Hornblenda & 0.24 & 97.70 & 0.09 & 2.30 & $\mathrm{u}$ & - & - & - \\
\hline Turmaline & 0.16 & 98.80 & 0.06 & 1.20 & - & - & - & - \\
\hline Other minerals* & 1.10 & - & - & - & $\mathrm{u}$ & - & - & - \\
\hline Clinoptilolite & 3.00 & - & - & - & 57.85 & 92.50 & 37.65 & 7.50 \\
\hline Analcime & - & - & - & - & 19.10 & 98.70 & 12.85 & 1.30 \\
\hline Sum 1 & 3.75 & - & - & - & 82.74 & 93.45 & 53.49 & 6.55 \\
\hline Silica ${ }^{(b)}$ & $\mathrm{U}$ & - & - & - & 6.58 & 98.95 & 4.43 & 1.05 \\
\hline Feldspars $^{(c)}$ & $\bar{U}$ & - & - & - & 9.93 & 97.25 & 6.63 & 2.75 \\
\hline Other minerals ${ }^{* \star}$ & $U$ & - & - & 1.75 & - & - & - & - \\
\hline Separated, $\%^{(a)}$ & \multicolumn{4}{|c|}{96.26} & \multicolumn{4}{|c|}{93.87} \\
\hline Loss, $\%^{(a)}$ & \multicolumn{4}{|c|}{5.30} & \multicolumn{4}{|c|}{6.13} \\
\hline
\end{tabular}

Experimental conditions: transversal slope $\theta=5^{\circ}$; longitudinal slope $\varphi=15^{\circ}$; intensity of the electromagnet supply power: $\mathrm{i}=1.10$ Ampers; separation speed: $7.72 \mathrm{~g} / \mathrm{min}$; granulation of the sample: $\Phi=0.160-0.100 \mathrm{~mm}$; temperature: $29.50^{\circ} \mathrm{C}$; initial quantity of the sample (volcanic tuff): $318.5983 \mathrm{~g}$. Notations: [\%]-percentage in the separated fraction; [\%]s-separated percentage from the initial quantity; $\Delta, \%$ - concentration coefficient (in separated fraction, in

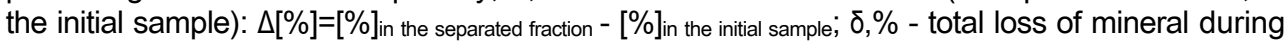
separation. *Identified minerals (X-ray diffraction, IR spectroscopy) in the paramagnetic fraction: (montmorillonite, zircon, clorite, limonite, goethite) \pm (clinoptilolite, heulandite, silica, feldspars); ${ }^{* *}$ Identified minerals in the diamagnetic fraction: (calcite, apatite, zircon, montmorillonite) \pm (volcanic glass, biotite); ${ }^{(a)}$ Reported to initial quantity of the separated mineral fraction; u-minerals present in the separated fraction in quantities less than $<0.1 \%$; ${ }^{(b)}$ Includes: quartz, opal, cristobalite; ${ }^{(\mathrm{c})}$ Includes: plagioclases + orthoclases. Analyst: D.Bulgariu. 
Both, to establish the optimum working conditions and for an accurate interpretation of the experimental results, 4 standardes have been prepared, with a granulation of $0.100-0.071 \mathrm{~mm}$, containing equal parts of the following minerals: first standrard: garnet + quartz + mica; second standard: quartz + turmaline + zircon; third standard: clinopioxene (augite) + siderite + calcite; forth standard: feldspars (orthoclase) + quartz + rhyolitic volcanic glass. The standardes undertook the separation procedure under the same conditions as the volcanic tuff samples.

\section{The experimental procedure}

After an adequate preliminary preparation, the volcanic tuff samples have been fractioned by using the magnetic method under the following conditions: longitudinal slope: $\varphi=15^{\circ}$, transversal slope: $\theta=5^{\circ}$; intensity of the supply power $i=1.1 \AA$ (the results are presented in table 1 ). Subsequently, as the approximate value of the optimum working parameters were known (from the data obtained at the separation of minerals from standardes), the separation of the minerals was done, both from the diamagnetic fraction and from the paramagnetic fraction.

The obtained monomineral fractions were purified after, using the heavy liquids methods, by extraction of the impurities with organic solvents and by electrophoresis. Using parallel samples, we make separations by heavy liquid method (table 2).

\section{EXPERIMENTAL RESULTS. DISCUTIONS}

In case of the zeolitic volcanic tuff, by using the heavy liquids method, a superior izolation degree of the mineral components cannot be realized, but this method allows an almost quantitative recovery of some of these mineral components. Except the $\phi_{3}$ and $\phi_{4}$ granulometric fractions, the recovery factors and the losses for the light fractions have acceptable values from an analytical point of view (tables 2 and 3 ). In ours case, the light fraction has been retrieved in a proportion $94.50-99.70 \%$, and the losses were of $0.35-0.45 \%$. However, the mineral concentration factors in the light fractions have very low values, generally between $1.80-3.65 \%$ (table 4). For the heavy fractions, the recovery factors and the separation losses have unacceptable values from analytical point of view. The recovery of the heavy fractions has been realized in proportion of $93.5-94.00 \%$, while the separation losses were of $6.00-6.30 \%$. The mineral concentration factors in the heavy fractions have higher values than the values corresponding to the minerals in the light fractions, generally between $23-40 \%$.

For the $\phi_{3}$ and $\phi_{4}$ granulometric fractions, the separations were done with much lower efficiency than the separations on the $\phi_{1}$ and $\phi_{2}$ granulometric fractions (table 2). In these cases, the light fractions were recovery only, in proportion of $98.15-99.00 \%$ and the heave fractions were recovery in proportion of $92.50-96.00 \%$. The losses recorded at the separations on these granulometric fractions has relatively high values: in the case of light fractions, the losses were of $0.90-1.85 \%$ and in the case of the heavy fractions, the losses were of $3.95-7.60 \%$. 
Table 2.

The results of the fractionation of a volcanic tuff sample (A.3-10 sample, riodacitic tuff, vitreocrystalloclastic, zeolitized) by the heavy liquid method.

\begin{tabular}{|c|c|c|c|c|c|c|c|c|}
\hline \multirow{3}{*}{$\begin{array}{c}\begin{array}{c}\text { Granulometric } \\
\text { fractions }\end{array} \\
\text { Specifications } \\
\end{array}$} & \multicolumn{2}{|c|}{$\begin{array}{c}\varnothing_{1} ; \mathrm{mm} \\
0.160-0.100 \\
\end{array}$} & \multicolumn{2}{|c|}{$\begin{array}{c}\varnothing_{2} ; \mathrm{mm} \\
0.100-0.071 \\
\end{array}$} & \multicolumn{2}{|c|}{$\begin{array}{c}\varnothing_{3} ; \mathrm{mm} \\
0.071-0.045 \\
\end{array}$} & \multicolumn{2}{|c|}{$\begin{array}{l}\varnothing_{4} ; \mathrm{mm} \\
<0.045\end{array}$} \\
\hline & Initial & Final & Initial & Final & Initial & Final & Initial & Final \\
\hline & 51.39 & $50.91^{a}$ & 50.04 & $49.61^{\mathrm{a}}$ & 50.29 & $49.93^{\mathrm{a}}$ & 51.68 & $51.00^{a}$ \\
\hline \multicolumn{9}{|c|}{ Light fraction (samples A.3-10 / FU) } \\
\hline [g] fraction & $46.73^{\mathrm{C}}$ & $46.56^{b}$ & $45.88^{\mathrm{C}}$ & $45.70^{b}$ & $45.74^{\mathrm{C}}$ & $45.31^{b}$ & $47.00^{\mathrm{C}}$ & $46.31^{b}$ \\
\hline [g] loss & \multicolumn{2}{|c|}{0.1975} & \multicolumn{2}{|c|}{0.1732} & \multicolumn{2}{|c|}{$0.4279^{\mathrm{e}}$} & \multicolumn{2}{|c|}{$0.8526^{\mathrm{e}}$} \\
\hline [\%] separated ${ }^{\mathrm{d}}$ & \multicolumn{2}{|c|}{99.57} & \multicolumn{2}{|c|}{99.62} & \multicolumn{2}{|c|}{$99.06^{\mathrm{e}}$} & \multicolumn{2}{|c|}{$98.18^{\mathrm{e}}$} \\
\hline [\%] loss ${ }^{\mathrm{d}}$ & \multicolumn{2}{|c|}{0.43} & \multicolumn{2}{|c|}{0.38} & \multicolumn{2}{|c|}{$0.94^{\mathrm{e}}$} & \multicolumn{2}{|c|}{$1.82^{\mathrm{e}}$} \\
\hline $\begin{array}{l}\text { Identificared } \\
\text { minerals }\end{array}$ & \multicolumn{2}{|c|}{$\begin{array}{l}\text { Glass } \\
\text { Clinoptilolite } \\
\text { Analcime } \\
\text { Silica* } \\
\text { Montmorillonite }\end{array}$} & \multicolumn{2}{|c|}{$\begin{array}{l}\text { Glass } \\
\text { Clinoptilolite } \\
\text { Analcime } \\
\text { Mordenite } \\
\text { Silica* } \\
\text { Montmorillonite }\end{array}$} & \multicolumn{2}{|c|}{$\begin{array}{l}\text { Glass } \\
\text { Clinoptilolite } \\
\text { Analcime } \\
\text { Mordenite } \\
\text { Silica* } \\
\text { Montmorillonite }\end{array}$} & \multicolumn{2}{|c|}{$\begin{array}{l}\text { Glass } \\
\text { Clinoptilolite } \\
\text { Analcime } \\
\text { Mordenite } \\
\text { Silica* } \\
\text { Montmorillonite } \\
\text { Calcite } \\
\text { Feldspars }\end{array}$} \\
\hline \multicolumn{9}{|c|}{ Heavy fraction (samples A.3-10 / FG) } \\
\hline [g] fraction & $4.65^{\mathrm{C}}$ & $4.37^{b}$ & $4.16^{\mathrm{C}}$ & $3.90^{\mathrm{b}}$ & $4.55^{\mathrm{C}}$ & $4.61^{b}$ & $4.67^{c}$ & $4.77^{b}$ \\
\hline [g] loss & \multicolumn{2}{|c|}{0.2797} & \multicolumn{2}{|c|}{0,2619} & \multicolumn{2}{|c|}{0.1802} & \multicolumn{2}{|c|}{0.3533} \\
\hline [\%] separated ${ }^{\mathrm{d}}$ & \multicolumn{2}{|c|}{93.98} & \multicolumn{2}{|c|}{93.70} & \multicolumn{2}{|c|}{96.04} & \multicolumn{2}{|c|}{92.44} \\
\hline$[\%] \operatorname{loss}^{d}$ & \multicolumn{2}{|c|}{6.02} & \multicolumn{2}{|c|}{6.30} & \multicolumn{2}{|c|}{3.96} & \multicolumn{2}{|c|}{7.56} \\
\hline $\begin{array}{l}\text { Identificated } \\
\text { minerals }\end{array}$ & \multicolumn{2}{|c|}{$\begin{array}{l}\text { Feldspars } \\
\text { Silica** }^{\dagger} \\
\text { Montmorillonite } \\
\text { Calcite } \\
\text { Muscovite } \\
\text { Hornblenda } \\
\text { Zircon } \\
\text { Apatite }\end{array}$} & \multicolumn{2}{|c|}{$\begin{array}{l}\text { Feldspars }{ }^{\dagger} \\
\text { Silica** }^{\star *} \\
\text { Montmorillonite } \\
\text { Calcite } \\
\text { Muscovite } \\
\text { Hornblenda } \\
\text { Zircon } \\
\text { Apatite }\end{array}$} & $\begin{array}{l}\text { Feldspa } \\
\text { Silica** } \\
\text { Montmc } \\
\text { Calcite } \\
\text { Muscov } \\
\text { Hornble } \\
\text { Zircon } \\
\text { Apatite } \\
\text { Glass } \\
\text { Clinopti }\end{array}$ & llonite & $\begin{array}{l}\text { Feldspa } \\
\text { Silica** } \\
\text { Montmo } \\
\text { Calcite } \\
\text { Muscov } \\
\text { Hornble } \\
\text { Zircon } \\
\text { Apatite } \\
\text { Glass } \\
\text { Clinoptil } \\
\text { Analcim }\end{array}$ & $\begin{array}{l}\text { Sllonite }^{f} \\
\text { da } \\
\text { lite }\end{array}$ \\
\hline
\end{tabular}

Work conditions: heavy liquid-bromoform (G.s. $=2.4854 \mathrm{~g} . \mathrm{cm}^{-3}$, at $22^{\circ} \mathrm{C}$ ); contact time between phases: 20 minutes. ${ }^{(a)}$ The sum of the two separated fractions; ${ }^{\left({ }^{(b)}\right.}$ Gravimetric determinations; ${ }^{(c)}$ Calculated on the basis of the results of the X-ray diffraction and IR spectroscopy; (d) $[\%$, grav.] from the fractions contained in volcanic tuff sample; ${ }^{(e)}$ Recalculated values on the basis X-ray diffraction and infrared spectroscopy analyses; (i) Includes: orthoclases + plagioclases; *Includes: opal și amorphous silica; ${ }^{* *}$ Includes: quartz și cristobalite; ${ }^{(h)}$ Identified minerals through X-ray diffraction analysis. Impurity in separated fractions. Analist: D.Bulgariu. 
Table 3.

The efficiency parameters of the separation method with heavy liquids applied to fractionation of a volcanic tuff (sample A.3-10, riodacitic tuff, vitreocrystalloclastic, zeolitized).

\begin{tabular}{|c|c|c|c|c|}
\hline Specifications & $\begin{array}{c}\varnothing_{1} ; \mathrm{mm} \\
0.160-0.100\end{array}$ & $\begin{array}{c}\varnothing_{2} ; \mathrm{mm} \\
0.100-0.071\end{array}$ & $\begin{array}{c}\varnothing_{3} ; \mathrm{mm} \\
0.071-0.045\end{array}$ & $\begin{array}{c}\varnothing_{4} ; \mathrm{mm} \\
<0.045\end{array}$ \\
\hline $\mathrm{R}_{\mathrm{fu}}$ & 0.9957 & 0.9952 & $0.9906^{*}$ & $0.9818^{*}$ \\
\hline $\mathrm{R}_{\mathrm{fg}}$ & 0.9398 & 0.9370 & $0.9604^{*}$ & $0.9244^{*}$ \\
\hline $\mathrm{S}_{\mathrm{u} / \mathrm{g}}$ & 1.0594 & 1.0631 & $1.0314^{*}$ & $1.0620^{*}$ \\
\hline
\end{tabular}

Notation: $R_{f u}-$ recovery factor for the light fraction; $R_{\mathrm{fg}}$-recovery factor for the heavy fraction; $\mathrm{S}_{\mathrm{u} / \mathrm{g}}$-separation factor for the light fraction. *Recalculated values on the basis of the X-ray diffraction analysis. The values of the analytical parameters were calculated on the basis of data from table 2 .

Table 4.

The efficiency parameters of the separation method with heavy liquids applied to the separation of minerals from a volcanic tuff (sample A.3-10, riodacitic tuff, vitreocrystalloclastic, zeolitized).

\begin{tabular}{|l|c|c|c|c|}
\hline $\begin{array}{c}\text { Granulometric } \\
\text { fraction }\end{array}$ & \multicolumn{3}{c|}{$\varnothing_{1}=0.160-0.100 \mathrm{~mm}$} & $\varnothing_{2}=0.100-0.071 \mathrm{~mm}$ \\
\hline \multicolumn{1}{|c|}{ Parameters } & $R$ & $\Delta, \%$ & $R$ & $\Delta, \%$ \\
\hline \multicolumn{5}{|c|}{ Samples A.3-10 / FU } \\
\hline Volcanic glass & 0.9973 & 6.34 & 0.9978 & 5.80 \\
\hline Clinoptilolite & 0.9943 & 2.08 & 0.9961 & 1.83 \\
\hline Analcime & 0.9914 & 0.59 & 0.9939 & 0.55 \\
\hline Total zeolites & 0.9923 & 2.70 & 0.9959 & 2.55 \\
\hline \multicolumn{5}{|c|}{ Samples A.3-10 / FG } \\
\hline Feldsprs* & 0.9663 & 34.19 & 0.9782 & 38.11 \\
\hline Silica** & 0.9364 & 21.51 & 0.9389 & 23.74 \\
\hline Other minerals & 0.9175 & 36.61 & 0.8883 & 30.47 \\
\hline
\end{tabular}

Notations: $R$-recovery factors; $\Delta, \%$ - concentration coefficient (see table 1); The values of the parameters have been calculated on the basis of data in table 2. *Includes: quartz, opal, cristobalite; **Includes: orthoclases and plagioclases.

In the case of separations on $\phi_{3}$ and $\phi_{4}$ granulometric fractions, a quite strong mutual contamination of the separated mineral fractions occurs and this fact reduces the applicability of this separation method. In case of separations on $\phi_{3}$ granulometric fraction, the X-ray diffraction and IR spectroscopy analysis were indicated for the light fraction (table 2), and real loss of $0.4279 \mathrm{~g}$, from which $0.2395 \mathrm{~g}$ contamined the heavy fraction. The effective loss at the separation of this fraction was of $0.1884 \mathrm{~g}$. In the case of the heavy fraction, the effective separation loss was of $0.1802 \mathrm{~g}$, even though experimentally, an increase with $0.0593 \mathrm{~g}$ of the mass of this fraction was determined. Similar data have been obtained in the case of separations on $\phi 4$ granulometric fraction (table 2). The 
main causes which determined the decrease of the separation output in the case of small granulometric fractions are: (1)-geochemical non-homogeneity of the rock granules and the mineral granules; (2)-adsorption and complexation phenomena on the surface of the rock granules; (3)-flotation and / or aglutination phenomena of the rock granules. The intensity of these phenomena is higher when inorganic heavy liquids are used.

For to eliminate the inconveniences which appear at the separation of the small granulometric fractions, we use two procedures: (1)-the bromoform solutions used for separation were more diluted and the contact time between the phases was reduced to half; (2)-the mineral fractions separating by the heavy liquid method, were subsequently purified means, by magnetic method, organic solvents extraction and electrophoresis.

In order to increase the fractionation capacity and the efficiency of the separation method with heavy liquids, we have successively used several separation stages ( 3 - 5 stages), with diluted solutions of the same heavy liquid, or different liquids (Clerici solution, Brauns solution and bromoform). Using this procedure, mineral fractions with maximum purity of $62 \%$ have been obtained.

In comparation with the separation method with heavy liquids, the separations by magnetic method require lower separation degrees, higher separation losses (table 1), but the concentration coefficients of the minerals and the purity of the separated mineral fractions have clearly, superior values (table 5). In ours case, the magnetic method not permited to obtain, directly the monomineral fractions. The average recovery degree of the paramagnetic fraction is $96.26 \%$ and for the diamagnetic fractions is $93.87 \%$ (table 1). The highest separation losses are recorded in the case of the paramagnetic fractions. Unlike the separation with heavy liquids, in the case of magnetic separation, the mutual contamination degree of the separated fractions is more reduced.

The zeolites, silica and feldspars are diamagnetic minerals, but the calculation of the magnetic susceptibilities indicated that some fractions of these minerals are caracterized by anormal paramgnetic properties. Thus, $7-12 \%$ of the clinoptilolite is separed as a weakly paramagnetic fractions: $X=(0.2884-0.4308) .10^{-6}$ [CGS] ( $X$ - specific magnetic susceptivity). In the case of analcime, the weakly paramagnetic fraction represents $1.50-3.50 \%$ of the total analcime amount: $\mathrm{X}=$ (0.2664 -0.3185). $10^{-6}$ [CGS].

The zeolites separation degree by using the magnetic separation method, for one passing of the sample through the separator, under optimum work conditions, is lower than in case of the separation with heavy liquids. After 3-5 passings of the sample through separator, mineral fractions with a zeolite content of $81.35-82.75 \%$ have been obtained. In these conditions, the zeolite separation degree was of $80.55-96.70 \%$ and the concentration coefficient was between $53.10-54.51 \%$. The analytical parameters coresponding to the analcime have lower values than in the case of the clinoptilolite.

In comparation with the separation method with heavy liquids, the efficiency of the magnetic separations can be influenced by several factors. Besides the work parameters, whose effects can be experimentally controled the efficiency of 
the magnetic separations is also influenced by a series of factors which depends to the structure of mineralogic - chemical composition of the studied samples. The effects of the latter factors are not so easily to predicted and controlled experimentally. These factos are: the structure and chemical-mineralogical composition of the samples, the ion-exchange and absorbtion phenomena, the granule dimensions and the way of association etc. The influences of these factors on the separation efficiency, can not be discussed yet, from quantitative point of view, although they are easily intuitive and qualitatively descriptible.

Table 5.

Efficiency parametres of the magnetic method applied to the fractionation of a volcanic tuff (sample A.3-10, riodacitic tuff, vitreocrystalloclastic, zeolitized).

\begin{tabular}{|c|c|c|c|c|c|c|}
\hline \multirow[t]{2}{*}{ Minerals } & \multirow[t]{2}{*}{ Sample* } & \multicolumn{2}{|c|}{ Work conditions } & \multirow[t]{2}{*}[\%]{$f$} & \multirow[t]{2}{*}[\%]{$\mathrm{s}$} & \multirow[t]{2}{*}{$\Delta[\%]$} \\
\hline & & $\theta[0]$ & i, Ampers & & & \\
\hline \multirow{4}{*}{ Clinoptilolite } & A.3-10 / 27 & 1.00 & 1.20 & 59.92 & 82.50 & 39.72 \\
\hline & A.3-10 / 30 & 1.50 & 1.20 & 58.29 & 89.40 & 38.09 \\
\hline & A.3-10/33 & 2.00 & 1.20 & 57.65 & 93.10 & 37.45 \\
\hline & A.3-10/35 & 2.50 & 1.20 & 56.27 & 93.55 & 36.07 \\
\hline \multirow{4}{*}{ Analcime } & A.3-10/27 & 1.00 & 1.20 & 21.67 & 96.45 & 15.42 \\
\hline & A.3-10/30 & 1.50 & 1.20 & 19.87 & 98.50 & 13.62 \\
\hline & A.3-10/33 & 2.00 & 1.20 & 18.87 & 98.50 & 12.62 \\
\hline & A.3-10/35 & 2.50 & 1.20 & 18.38 & 98.80 & 12.13 \\
\hline \multirow{4}{*}{ Total zeolites } & A.3-10/27 & 1.00 & 1.20 & 81.82 & 80.55 & 53.37 \\
\hline & A.3-10/30 & 1.50 & 1.20 & 82.76 & 90.75 & 54.51 \\
\hline & A.3-10/33 & 2.00 & 1.20 & 81.41 & 94.00 & 53.16 \\
\hline & A.3-10/35 & 2.50 & 1.20 & 81.35 & 96.70 & 53.10 \\
\hline \multirow[t]{2}{*}{ Silica } & A.3-10/27 & 1.00 & 1.20 & 6.04 & 78.25 & 3.89 \\
\hline & A.3-10/30 & 1.50 & 1.20 & 6.13 & 88.45 & 3.98 \\
\hline \multirow[t]{2}{*}{ Feldspars } & A.3-10/27 & 1.00 & 1.20 & 10.06 & 84.80 & 6.76 \\
\hline & A.3-10/30 & 1.50 & 1.20 & 9.75 & 91.60 & 6.45 \\
\hline \multirow[t]{2}{*}{ Volcanic glass } & A.3-10/2 & 2.5 & 0.20 & 99.78 & 83.50 & 37.08 \\
\hline & A.3-10/5 & 5.0 & 0.30 & 99.75 & 89.00 & 37.05 \\
\hline Biotite & A.3-10 / 4 & 5.0 & 0.25 & 4.50 & 69.70 & 4.35 \\
\hline Muscovite & A.3-10/15 & 25 & 0.80 & 3.49 & 71.34 & 3.32 \\
\hline Turmaline & A.3-10/9 & 15 & 0.60 & 0.58 & 92.55 & 0.47 \\
\hline
\end{tabular}

Notations: [\%] $]_{\mathrm{r}}$ percentages in the separated fraction; [\%] initial quantity; $\Delta, \%$ - concentration coefficient: *The fractions separated at different values of the work parameters. $\Theta\left[{ }^{\circ}\right]$-transversal slope; $i$ - intensity of the electromagnet supply power.

During the separation of the small granulometric fractions $(\varnothing<0.071 \mathrm{~mm})$ appear frequent, secondary magnetization phenomena which determined invariantly, the apparition of the magnetic flocculency effects. The global effect is represented by the significant diminution of the separation efficiency and the reduction of the possibility to estabilishing the optimum work parameters accurately. The secondary magnetization phenomena have been also observed 
in the case of the samples with cu $\varnothing>0.071 \mathrm{~mm}$, at relatively high intensities of the supply power ( $i>1.1$ Ampers). On these cases, the influences on the separation efficiencies are insignificant.

The heterogeneity of the structure and chemical-mineralogical composition of the granules represents one the main factors which can modify significantly, the efficiency of the magnetic separations. In general, the influences of this factor is reflected in: widening of the mineral separation intervals; the reduction of the recuperation degree; the diminution of the estimation accuracy of optimum work parameters.

\section{CONCLUSIONS}

For the separation with heavy liquids, although the technique we have used is fast and does not require sophisticated apparatus, this method presents several practical inconveniences: (1)-the risk of sample contamination and deterioration; (2)-if is applied in only one stage and singularly way, it not permited of efficient separations.

By, separation methods with heavy liquids, in experimental variants applied by as, mineral fractions with a zeolite content of $53.46-62.50 \%$ have been obtained. The magnetic methods, applied to samples of rude volcanic tuff, mineral fractions with a zeolite content of 83-95 \% were obtained. The risk of sample contamination is lower than in the case of the heavy liquids separation. The major difficulties encountered when using this method is determinated by the adequate calibration of the izodynamic separator and the estableishing of the optimum work conditions. The experimental strategy proposed by as, applied to the zeolitic volcanic tuffs, allows the obtaining of several mineral fractions with advanced purity (over $98.50 \%$ ), is flexible and can also be applied, with minor modifications in the case other types of geological samples.

\section{REFERENCES}

Anastasiu, N. (1986), Petrologie sedimentară . Editura Tehnică , București.

Bă rbat, A., Marton, Al. (1989), Tufurile vulcanice zeolitice. Editura Dacia, Cluj Napoca.

Bedelean, I., Stoici, S.D. (1986), Zeoliț i. Editura Tehnică , București.

Bulgariu, D. (1999), The determination of the zeolites from the volcanic tuffs throug X-ray diffraction (Part I). Analele Știint ifice ale Universită ții „Al.I.Cuza" Iași. s.Geologie, Tom XLV (in press).

Bulgariu, D. (2002), Aspecte geochimice ale procesului de zeolitizare a unor tufuri vulcanice din România (teză de doctorat). Universitatea „Al.I.Cuza" lași, Facultatea de Geografie și Geologie.

Febinskii, V.V., Gurbici, I.I., Dimitriev, V.I. et al. (1976), Fiziceskie svoistva gornîh porod i poleznîh iskopaemîh. Petrogrofizica, Nedra, Moskva. 
Flinter, B.H. (1959), Magnetic Separation of Some Alluvial Minerals in Malaya. American Mineralogist., 44, 738-751.

lorga, N. (1989), Metode fizice de studiu a mineralelor și rocilor. Editura Universită ții. „Al.I. Cuza" lași.

Jercan, E. (1983), Metode de separare în chimia analitică . Editura Tehnică , București.

Lă că tușu, R. (2000), Mineralogia și chimia solului. Editura Universită ț ii „Al.I.Cuza" lași.

Liteanu, C., Bold, A., Gocan, S. (1981), Separatologie analitică . Editura Dacia, Cluj Napoca.

McBride, M.B. (1986), Magnetic Methods. În: Methods of Soil Analysis, Part 1. Physical and Mineralogical Methods. American Society of Agronomy - Soil Science Society of America, Madison, SUA, 219-270.

McAndrew, J. (1957), Calibration of a Frantz Separator and its Application to Mineral Separation. Proceedings the Australian I.M.M., 181, 59-73.

Sabliovschi, V., Bulgariu, D. (2001 a), Iron Oxydes and Oxyhydroxides (Hydrogoethite, Hydrohematite, Ferohydrite, Hematite) from Mineral Fractions of Histosols on Dornelor Bassin, Lucră rile celei de a XVI-a Conferint, e Naționale pentru Științ a Solului. vol. 30.A (2001), 219-227.

Sabliovschi, V., Bulgariu, D. (2001 b), Opal and Calcedony Mineral Fractions from Dorna Bassin, Lucră rile celei de a XVI-a Conferinț eNaționale pentru Șiinț a Solului. vol. 30.A (2001), 228-235.

Tueva, M.N. (1954), Practicescoe rukovoddstvo po razdeleniu mineralov $v$ teajelîh jiidkosteah i soleah. Nedra, Moskva. 